\title{
Fluoride Desorption of Secondary Alumina at High Temperatures ${ }^{\dagger}$ \\ Youjian YANG, Bingliang GAO,* Jiangyu YU, Zhaowen WANG, Zhongning SHI, and Xianwei HU
}

\author{
School of Materials \& Metallurgy, Northeastern University, Shenyang 110004, China \\ *Corresponding author: gaobl@smm.neu.edu.cn
}

\begin{abstract}
Primary alumina is used as the raw material as well as the sorbent for fluoride in aluminum electrolysis. Secondary alumina is the product of primary alumina after absorbing fluoride in exhaust pot gas. The fluorine and mass loss during heating secondary alumina was measured to study the fluoride desorption process of alumina. It was found that during the heating of secondary alumina, $\mathrm{HF}$ emission was always combined with $\mathrm{H}_{2} \mathrm{O}$ escape at approximately $740^{\circ} \mathrm{C}$ or below. $47 \%$ fluorine in secondary alumina desorbed in the form of $\mathrm{HF}$ at $30-740^{\circ} \mathrm{C}$, while the rest $53 \%$ desorbed in the form of chiolite at $740-1100^{\circ} \mathrm{C}$.
\end{abstract}

(c) The Electrochemical Society of Japan, All rights reserved.

Keywords : Aluminum Electrolysis, Secondary Alumina, See-through Cell, Fluoride Desorption

\section{Introduction}

Due to the vaporization and hydrolysis of the aluminum bath, aluminum smelting cells produce fluoride emissions consisting of sodium aluminum fluoride and hydrogen fluoride. ${ }^{1}$ Considering environmental and economic aspects, primary alumina (manufactured/fresh alumina) is widely used as sorbent in the dry scrubbing system for the capture of gaseous and particulate fluoride, with an efficiency of $98 \%$ (Fig. 1). Secondary alumina, which is the corresponding byproduct of this process, is also added into the smelting cell to reduce fluorine loss.

Smelter-based fluoride evolution and recovery chemistry was first addressed at Alcoa in $1971 .^{2}$ Many researchers have studied the effects of physical and chemical properties of alumina on the adsorption capacity for gaseous $\mathrm{HF}$ and solid dust. Several mechanisms of $\mathrm{HF}$ adsorption have been proposed to reconcile the results of XRD, XPS, NMR, TGA, and DSC and so on. ${ }^{3,4}$ The chemical and physical adsorption of $\mathrm{HF}$ at room temperature may correspond to desorption of fluoride during feeding. This paper is mainly focused on the desorption reaction, reaction rate, desorption composition and quantity. Combined with adsorption mechanism, the mechanism of fluorine desorption is discussed in this paper.

\section{Experimental}

Primary alumina and its corresponding byproduct—secondary alumina samples used in this study were taken from aluminum smelting plant. After reaction in the dry scrubber, secondary alumina contains a bit more fine particles than primary alumina as can be observed from size distribution measurement. Since it doesn't affect the results of fluorine content and TGA analysis, it is neglected.

\subsection{Fluorine content determination}

Secondary alumina samples were preheated at different temperatures respectively for $2 \mathrm{~h}$, and then extracted with $0.01 \mathrm{~mol} \cdot \mathrm{L}^{-1} \mathrm{NaOH}$ solution to free its fluorine ion and a fluorine ion selective electrode (PF-1 style from INESA Scientific Instrument Co., Ltd.) was used to determine the fluorine content of the solution. The fluorine concentration of each sample was measured for three times to check the

TPresented at the 4th Asian Conference on Molten Salt Chemistry and Technology

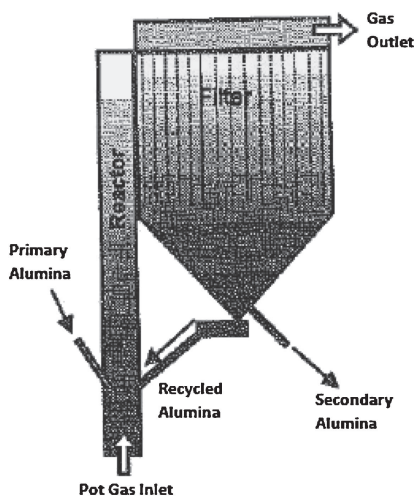

Figure 1. Traditional co-current dry scrubber. ${ }^{5}$

reproducibility. The results turned out to be of good reproducibility and the final data was taken as the average value of three determinations.

\subsection{TGA measurement}

The weight loss of primary alumina and its corresponding secondary alumina samples during heating was measured by the using of NETZSCH STA $409 \mathrm{C} / \mathrm{CD}$ equipment from 30 to $1100^{\circ} \mathrm{C}$ with a rate of $10^{\circ} \mathrm{C} \cdot \mathrm{min}^{-1}$ in high purity corundum cells, with $50 \mathrm{ml} \cdot \mathrm{min}^{-1}$ argon protection. The results were calculated based on the same mass of samples.

\subsection{XRD measurement}

Diffraction data of the volatilization of aluminum bath was collected by the using of $\mathrm{Cu}-\mathrm{K} \alpha$ radiation equipped on PANalytical PW3040/60 X' Pert Pro MPD diffractometer. The total scan time was $1020 \mathrm{~s}$ with an angular range of $5-90^{\circ}(2 \theta)$.

\section{Results and Discussion}

\subsection{Fluorine loss of heated secondary alumina}

The fluorine contents of secondary alumina heated at different temperatures are shown in Fig. 2.

As is shown in Fig. 2, the fluorine content of secondary alumina decreased linearly from 110 to $800^{\circ} \mathrm{C}$. Then it showed a sharper decrease from 800 to $1100^{\circ} \mathrm{C}$ where fluorine content went to zero. The faster desorption rate of latter interval suggests a different desorption modality of fluorine. 


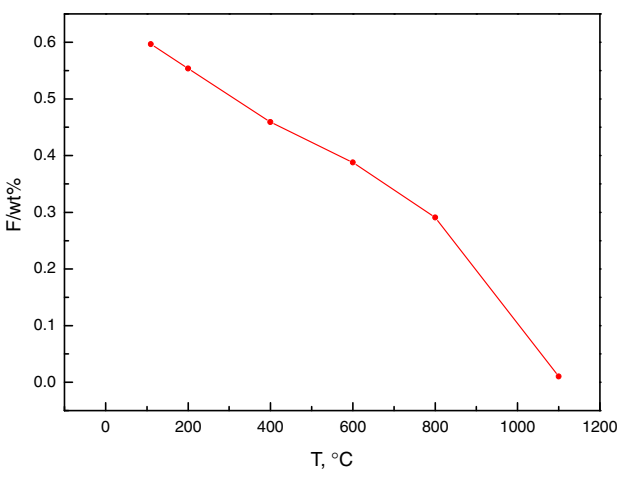

Figure 2. (Color online) Fluorine content of heated secondary alumina.

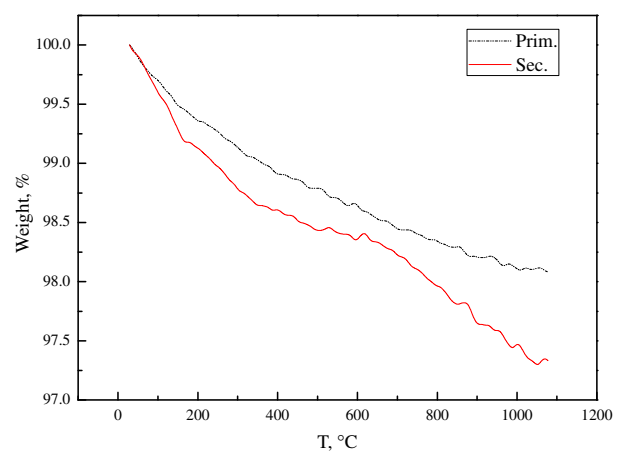

Figure 3. (Color online) TGA curves of primary alumina and secondary alumina.

\subsection{TGA analysis}

Both primary alumina and secondary alumina processes the loss of moisture and hydroxyl when heated to $1100^{\circ} \mathrm{C}$. The fluorine desorption of secondary alumina also occurred in this period. The TGA curves of primary and secondary alumina are shown together in Fig. 3.

As is shown in Fig. 3, TGA curve of primary alumina showed a gradual loss of weight as the temperature increased. While the secondary alumina showed a multistage weight loss compared to primary alumina, which corresponds to different desorption reactions and desorption rates. Subtract the weight loss of primary alumina from that of secondary alumina, the difference value (Dvalue) curve demonstrated an apparent multistage fluorine loss of secondary alumina as shown in Fig. 4. Figure 2 is overlapped into Fig. 4 for easy understanding.

According to the slope of $\mathrm{D}$-value curve, the fluorine desorption can generally be divided into four stages: $30-170^{\circ} \mathrm{C}, 170-350^{\circ} \mathrm{C}$, $350-740^{\circ} \mathrm{C}$, and $740-1100^{\circ} \mathrm{C}$. The data variations in $\mathrm{D}$-value curve were caused by fluoride loss and excessive dehydration of secondary alumina at each stage compared to primary alumina. Desorption of the fluoride in these four stages are discussed separately as follows.

Fluoride desorption from 740 to $1100^{\circ} \mathrm{C}$ : Since secondary alumina adsorbed emissions generated by bath evaporation from the aluminum cell, the fluoride will volatilize again when it is heated to a high temperature. In order to make sure the contents of the emissions, the volatile dust of aluminum bath was collected with an iron plate and its XRD patterns is shown in Fig. 5.

As can be seen in Fig. 5, the solid volatile of aluminum bath was mainly consisted of chiolite $\left(\mathrm{Na}_{5} \mathrm{Al}_{3} \mathrm{~F}_{14}\right)^{6}$ and $\mathrm{Fe}_{3} \mathrm{O}_{4}{ }^{7}$ which comes from the iron baseplate of the collection unit.

According to Fig. 4, the weight loss from 740 to $1100^{\circ} \mathrm{C}$ was $0.5100 \%$. Correspondingly, the fluorine loss was $0.2888 \%$. Supposing that the volatile matter was some kind of fluoride, then the fluorine content of the fluoride is $0.2888 \% / 0.5100 \%=56.6 \%$, which is very close to that of chiolite $(\% \mathrm{~F}=57.6 \%)$.

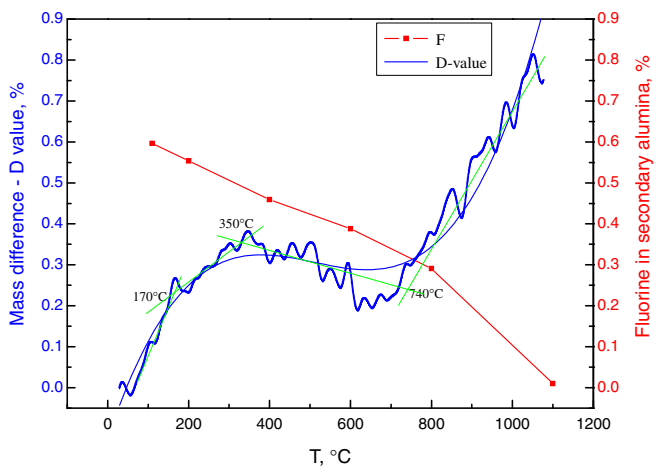

Figure 4. (Color online) D-value curve of weight loss of secondary alumina during heating.

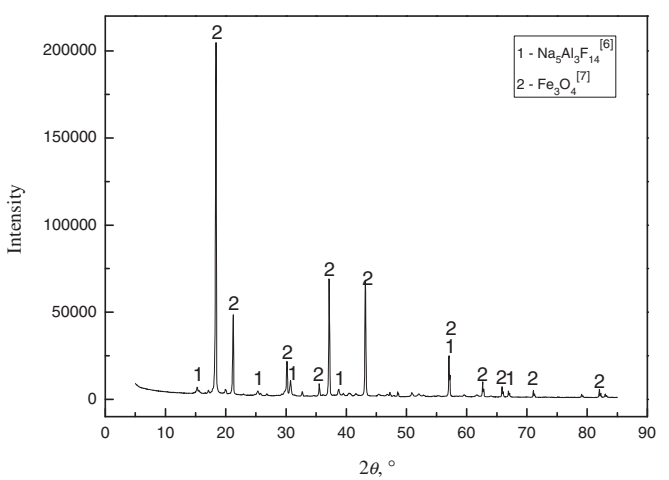

Figure 5. XRD patterns of collected dust from bath emissions.

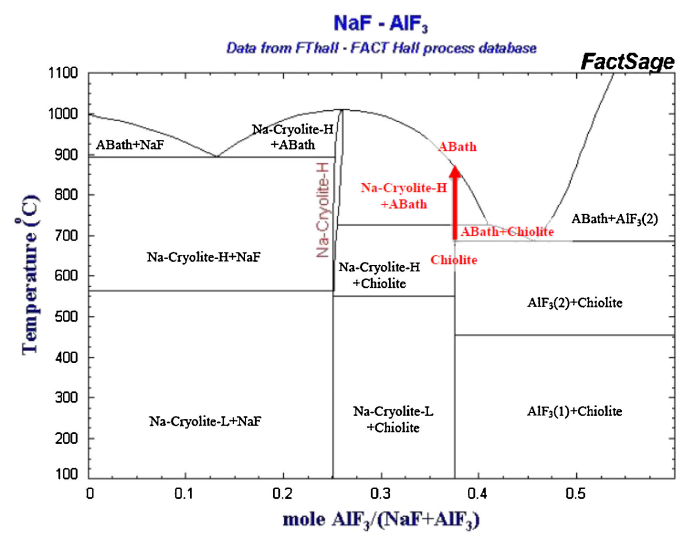

Figure 6. (Color online) Binary phase diagram of $\mathrm{NaF}_{-}-\mathrm{AlF}_{3}{ }^{8}$

Figure 6 shows the binary phase diagram of $\mathrm{NaF}_{-} \mathrm{AlF}_{3}{ }^{8}{ }^{8}$ Chiolite, with $37.5 \mathrm{~mol} \% \mathrm{AlF}_{3}$, reaches up to peritectic point when heated to $725^{\circ} \mathrm{C}$. As the temperature goes up, liquid phase appears, following with fluoride volatile emissions. When it reaches up to liquids temperature $\left(860^{\circ} \mathrm{C}\right)$, all chiolite turns into liquid phase.

Some agglomerates which may be caused by the reaction of alumina with sodium aluminum fluoride were observed in secondary alumina samples heated at $800^{\circ} \mathrm{C}$ or higher.

Results of XRD analysis, fluorine content of lost fluoride and the $\mathrm{NaF}-\mathrm{AlF}_{3}$ phase diagram all lead to a conclusion: the emissions of secondary alumina from 740 to $1100^{\circ} \mathrm{C}$ are consisted of sodium aluminum fluoride dust (mainly chiolite).

Fluoride desorption from 30 to $740^{\circ} \mathrm{C}$ : According to Fig. 3, from $30-1000^{\circ} \mathrm{C}$, the overall mass and fluorine loss was $0.8388 \%$ and $0.5987 \%$ separately. Since in the temperature range of 740 $1100^{\circ} \mathrm{C}$, chiolite went out with fluorine loss of $0.5100 \% * 57.6 \%$ $(\% \mathrm{~F}$ of chiolite $)=0.2938 \%$, so fluorine loss during this period should be modified as $0.5987 \%-0.2938 \%=0.3099 \%$ and mass 
Table 1. Fluorine loss and its corresponding fluoride during heating.

\begin{tabular}{ccc}
\hline Temperature, ${ }^{\circ} \mathrm{C}$ & $\% \mathrm{~F}(\mathrm{HF})$ & $\% \mathrm{~F}$ (Chiolite) \\
\hline $30-170$ & 4.60 & 0 \\
\hline $170-350$ & 14.38 & 0 \\
\hline $350-740$ & 27.63 & 0 \\
\hline $740-1100$ & 0 & 53.39 \\
\hline \multirow{2}{*}{ Overall } & 46.61 & 53.39 \\
\cline { 2 - 3 } & & 100.00 \\
\hline
\end{tabular}

loss should be $0.8388-0.5100=0.3288 \%$. Supposing that the fluorine went out in some form of fluoride, the fluorine content of this assumptive fluoride should be $0.3099 \%$ (fluorine change)/ $0.3288 \%$ (mass change) $=94.25 \%$, which is very close to that of HF component $(\% \mathrm{~F}=95 \%)$.

Study on the fluoride desorption of secondary alumina during heating should trace back to the adsorption process of primary alumina for aluminum pot gas. According to Lamb model, ${ }^{9}$ the chemisorption of hydrogen fluoride is a two-step reaction. Firstly the fluorine ion within hydrogen fluoride is adsorbed on alumina, substituting the hydroxyl groups initially chemisorbed on alumina and forming the monolayer (Reaction 1). Secondly the multistage adsorption of HF molecules occurs via the formation of hydrogen bonds (Reaction 2). In the presence of moisture, multilayers are relatively stable [see (3)]. Hydrogen bonds become weaker as they get further away from the chemisorbed layer. ${ }^{10}$

On the basis of Lamb model, Neal R. Dando proposed that the chemisorbed HF occurs on chemically active sites of the alumina surface in the formation of $\mathrm{AlF}_{3} \cdot \mathrm{nH}_{2} \mathrm{O}$ and $\mathrm{NaF}_{n} \mathrm{nH}_{2} \mathrm{O}$ complexes. ${ }^{11}$ Other researchers concluded that the physical adsorption of HF works through the hydroxyl groups and physically adsorbed moisture with the formation of $\mathrm{HF}$ and $\mathrm{H}_{2} \mathrm{O}$ layers. Both these conclusions made a point of hydroxyl and moisture in alumina. ${ }^{12}$ When secondary alumina is added into smelting cells, a sudden heating up is unavoidable, accompanied with the loss of most hydroxyl and moisture.

$$
\begin{aligned}
& \mathrm{Al}-\mathrm{OH}+\mathrm{HF}=\mathrm{Al}-\mathrm{F}+\mathrm{H}_{2} \mathrm{O}, \\
& \mathrm{Al}-\mathrm{F}+2 \mathrm{HF}=\mathrm{Al}-\mathrm{F} \cdots \mathrm{H}-\mathrm{F} \cdots \mathrm{H}-\mathrm{F}, \\
& \mathrm{Al}-\mathrm{F} \cdots \mathrm{H}^{\prime} \mathrm{H}^{\prime}-\mathrm{F} \cdots \mathrm{H}^{\prime} \\
& \mathrm{Al}-\mathrm{H}-\mathrm{F} \cdots \mathrm{H}^{\prime} \mathrm{H}-\mathrm{F} \cdots \mathrm{H}^{\prime}{ }^{\prime} \mathrm{H}-\mathrm{F} \cdots \text { etc. }
\end{aligned}
$$

As the lost of hydroxyl and moisture during heating, hydrogen bonds get weaker. Bonds broken first take place on the further hydrogen from the chemisorbed layer (Reaction 4). In the present paper, samples heated at $1100^{\circ} \mathrm{C}$ for $2 \mathrm{~h}$ contained no fluorine, which means the generated AlFx combined with chiolite and formed eutectic fluoride.

$$
\begin{aligned}
& \mathrm{Al}-\mathrm{F} \cdots \mathrm{H}_{\mathbf{O}^{\prime}}, \mathrm{H}-\mathrm{F} \cdots \mathrm{H}_{3}, \mathrm{H}-\mathrm{F} \cdots \text { etc. } \\
& \mathrm{Al}-\mathrm{F} \cdots \mathrm{H}^{\prime}{ }_{\mathrm{H}-\mathrm{F}} \cdots \mathrm{H}^{\prime} \mathrm{O}-\mathrm{H}-\mathrm{F} \text { etc. } \\
& =\mathrm{Al}-\mathrm{F}+\mathrm{H}_{2} \mathrm{O}+\mathrm{HF}
\end{aligned}
$$

Fluorine loss of secondary alumina during heating is listed in Table 1.

Fluoride desorption from 30 to $170^{\circ} \mathrm{C}$ : According to data in Fig. 4, the mass and fluorine lost during this period was $0.1738 \%$ and $0.0327 \%$ respectively. The fluorine content of the volatile is $0.0327 \%$ (fluorine change) $/ 0.1738 \%$ (mass change) $=18.83 \%$. Supposing that all the fluorine escaped as HF, the content of HF was $18.83 \% / 95 \%(\% \mathrm{~F}$ of $\mathrm{HF}$ gas $)=19.82 \%$, and the $\mathrm{H}_{2} \mathrm{O}$ percentage in the volatile was $100 \%-19.82 \%=80.18 \%$. Since the moisture and hydroxyl has been deducted from D-value curve, this part of excessive dehydration directly caused an over glissade of the
Table 2. The composition of emissions from secondary alumina in different temperature intervals.

\begin{tabular}{ccccc}
\hline $\begin{array}{c}\mathrm{T} \\
{ }^{\circ} \mathrm{C}\end{array}$ & $\begin{array}{c}\% \mathrm{~F} \\
(\mathrm{HF})\end{array}$ & $\% \mathrm{H}_{2} \mathrm{O}$ & $\begin{array}{c}\% \mathrm{~F} \\
(\text { Chiolite })\end{array}$ & $\begin{array}{c}\text { Overall } \\
\%\end{array}$ \\
\hline $30-170$ & 19.82 & 80.18 & 0 & 100.00 \\
\hline $170-350$ & 28.45 & 71.55 & 0 & 100.00 \\
\hline $350-740$ & 59.37 & 58.38 & 0 & 100.00 \\
\hline $740-1100$ & 0 & 0 & 100 & 100.00 \\
\hline
\end{tabular}

following mass data. The mass data from D-value curve is modified with excessive dehydrated water in the next stages.

Fluoride desorption from 170 to $350^{\circ} \mathrm{C}$ : During this period, the mass and fluorine loss was $0.1326 \%$ and $0.0876 \%$ respectively. But this mass change did not include the premature water loss below $170^{\circ} \mathrm{C}$ as mentioned above. $\mathrm{H}_{2} \mathrm{O}$ escaped (Reaction 4) below $170^{\circ} \mathrm{C}$ was $0.2388 \%$ (D-value at $\left.170^{\circ} \mathrm{C}\right) * 80.18 \%\left(\mathrm{H}_{2} \mathrm{O}\right.$ percentage of volatile at $\left.30-170^{\circ} \mathrm{C}\right)=0.1915 \%$. So the calibrated mass decreased at $170-350^{\circ} \mathrm{C}$ was $0.1326 \%$ (mass loss) $+0.1915 \%$ (calibration) $=$ $0.3241 \%$. It was calculated that $\mathrm{HF}$ and $\mathrm{H}_{2} \mathrm{O}$ takes proportion of $28.45 \%$ and $71.55 \%$ respectively.

Fluoride desorption from 350 to $740^{\circ} \mathrm{C}$ : With the same method as above, the mass and fluorine loss of this period from Fig. 3 was $-0.1451 \%$ and $0.1587 \%$. The amount of $\mathrm{H}_{2} \mathrm{O}$ lost during 170 $350^{\circ} \mathrm{C}$ was $0.3241 \%\left(\mathrm{D}\right.$-value at $\left.350^{\circ} \mathrm{C}\right) * 71.55 \%\left(\mathrm{H}_{2} \mathrm{O}\right.$ percentage of volatile at $\left.350-740^{\circ} \mathrm{C}\right)=0.2319 \%$. The mass loss of this period should be calibrated as $-0.1451 \%$ (mass change) $+0.2319 \%$ (over lost water at $170-350^{\circ} \mathrm{C}$ ) $+0.1915 \%$ (over lost water at below $\left.170^{\circ} \mathrm{C}\right)=0.2814 \%$. As a result, $\mathrm{HF}$ and $\mathrm{H}_{2} \mathrm{O}$ take up to $59.37 \%$ and $58.38 \%$ respectively.

Overall, the approximately composition of emissions from 30 $1100^{\circ} \mathrm{C}$ is shown in Table 2.

\section{Conclusions}

Fluoride desorption occurred during the preheating of secondary alumina. At the temperature of $30-740^{\circ} \mathrm{C}$, the emission of hydrogen fluoride and $\mathrm{H}_{2} \mathrm{O}$ was dominant. Desorption of $\mathrm{HF}$ was always combined with $\mathrm{H}_{2} \mathrm{O}$ lost. As the temperature increased to $740^{\circ} \mathrm{C}$, $\mathrm{HF}$ ratio in desorption rose from 19.82 to $59.37 \%$. At the temperature of $740-1100^{\circ} \mathrm{C}$, the volatilization of sodium aluminum fluoride (mainly chiolite) dust gained in importance. In this period, the residual $53.39 \%$ fluorine in secondary alumina got lost.

\section{Acknowledgment}

The authors would like to express their gratitude for the financial support by the National Basic Research Program of China (No. 2007CB210305) and the National Natural Science Foundation of China (Grant No. 51074045).

\section{References}

1. A. B. Heiberg, G. Wedde, O. K. Bøckman, and S. Ole Strømmen, Light Met., 255 (1999).

2. C. N. Cochran, W. C. Sleppy, and W. B. Frank, J. Met., 22(9), 54 (1970).

3. J. F. Coyne, M. S. Wainwright, and M. P. Brungs, Light Met., 113 (1989).

4. J. F. Coyne, M. S. Wainwright, and M. P. Brungs, Light Met., 35 (1987).

5. G. Wedde, Light Met., 183 (1997).

6. C. Brosset, Phase Transitions, 38, 127 (1992).

7. M. E. Fleet, J. Solid State Chem., 62, 75 (1986).

8. P. Chartrand and A. D. Pelton, Light Met., 245 (2002).

9. W. D. Lamb, Light Met., 425 (1978).

10. N. V. Vasyunina, I. P. Vasyunina, Y. G. Mikhalev, and A. M. Vinogradov, Metall. Nonferrous Met., 51, 447 (2010).

11. N. R. Dando, Light Met., 133 (2005).

12. M. Baverez and R. D. Marco, J. Met., 32(1), 10 (1980). 